\title{
Reviews and syntheses: Heterotrophic fixation of inorganic carbon - significant but invisible flux in environmental carbon cycling
}

\author{
Alexander Braun ${ }^{1}$, Marina Spona-Friedl ${ }^{1}$, Maria Avramov ${ }^{1}$, Martin Elsner ${ }^{1,2}$, Federico Baltar ${ }^{3}$, Thomas Reinthaler ${ }^{3}$, \\ Gerhard J. Herndl $^{3,4}$, and Christian Griebler ${ }^{1,3}$ \\ ${ }^{1}$ Institute of Groundwater Ecology, Helmholtz Zentrum München, Ingolstaedter Landstrasse 1, 85764 Neuherberg, Germany \\ ${ }^{2}$ Department of Analytical Chemistry and Water Chemistry, Technical University of Munich, Munich, Germany \\ ${ }^{3}$ Department of Functional and Evolutionary Ecology, University of Vienna, Althanstrasse 14, 1090 Vienna, Austria \\ ${ }^{4}$ Department of Marine Microbiology and Biogeochemistry, Royal Netherlands Institute for Sea Research, Utrecht University, \\ P.O. Box 59, 1790 AB Den Burg, the Netherlands
}

Correspondence: Christian Griebler (christian.griebler@univie.ac.at)

Received: 10 December 2020 - Discussion started: 17 December 2020

Revised: 3 May 2021 - Accepted: 17 May 2021 - Published: 21 June 2021

\begin{abstract}
Heterotrophic $\mathrm{CO}_{2}$ fixation is a significant yet underappreciated $\mathrm{CO}_{2}$ flux in environmental carbon cycling. In contrast to photosynthesis and chemolithoautotrophy - the main recognized autotrophic $\mathrm{CO}_{2}$ fixation pathways - the importance of heterotrophic $\mathrm{CO}_{2}$ fixation remains enigmatic. All heterotrophs - from microorganisms to humans - take up $\mathrm{CO}_{2}$ and incorporate it into their biomass. Depending on the availability and quality of growth substrates, and drivers such as the $\mathrm{CO}_{2}$ partial pressure, heterotrophic $\mathrm{CO}_{2}$ fixation contributes at least $1 \%-5 \%$ and in the case of methanotrophs up to $50 \%$ of the carbon biomass. Assuming a standing stock of global heterotrophic biomass of 47-85 Pg C, we roughly estimate that up to $5 \mathrm{PgC}$ might be derived from heterotrophic $\mathrm{CO}_{2}$ fixation, and up to $12 \mathrm{Pg} \mathrm{Cyr}^{-1}$ originating from heterotrophic $\mathrm{CO}_{2}$ fixation is funneled into the global annual heterotrophic production of 34-245 $\mathrm{Pg} \mathrm{C} \mathrm{yr}^{-1}$. These first estimates on the importance of heterotrophic fixation of inorganic carbon indicate that this pathway should be incorporated in present and future carbon cycling budgets.
\end{abstract}

\section{Introduction}

Fixation of $\mathrm{CO}_{2}$ is a fundamental biosynthetic process in nature (Beer et al., 2010; Berg et al., 2007), providing the main source of metabolic energy on Earth (Giovannoni and Stingl, 2005). At the same time, it acts as a sink for atmospheric $\mathrm{CO}_{2}$, the most important greenhouse gas, which is responsi- ble for more than $60 \%$ of the "enhanced greenhouse effect" resulting in global warming (Beer et al., 2010; Berg, 2011; Houghton, 2007; Le Quéré et al., 2016).

While photosynthesis and chemosynthesis are the most important processes of carbon fixation, non-autotrophic carbon fixation, i.e., the carbon fixation mediated by heterotrophic organisms, might also be relevant, albeit uncommonly quantified. While heterotrophs are, per definition, organisms that respire organic compounds to gain energy and build up biomass, $\mathrm{CO}_{2}$ fixation plays also an essential role in heterotrophic carbon metabolism. The diversity of carboxylating enzymes in nature reaches far beyond autotrophy and virtually all heterotrophs harbor numerous enzymes fixing dissolved inorganic carbon. Even though the first carboxylase in heterotrophs was discovered more than 80 years ago (Wood and Werkman, 1936), the role of heterotrophs in carbon cycling has so far largely focused on the oxidation of organic substrates using oxygen or alternative electron acceptors (e.g. nitrate, ferric iron, sulfate) and the production of $\mathrm{CO}_{2}$. Similar to the $\mathrm{CO}_{2}$ fixation by autotrophs, "heterotrophic $\mathrm{CO}_{2}$ fixation" might, however, constitute a significant carbon flux in specific habitats. The relevance of this process has hardly been quantified due to the lack of reliable estimates of heterotrophic $\mathrm{CO}_{2}$ fixation for most organisms and habitats, and the presumption that $\mathrm{CO}_{2}$ fixation in natural environments is restricted to autotrophic organisms.

To fill this gap, we review the current knowledge on (i) the role of heterotrophic $\mathrm{CO}_{2}$ fixation for cellular 
metabolism, (ii) respiration and non-autotrophic $\mathrm{CO}_{2}$ fixation, and (iii) $\mathrm{CO}_{2}$ fixation in habitats dominated by heterotrophs, and we provide (iv) quantitative estimates of heterotrophic $\mathrm{CO}_{2}$ fixation in different environments.

\section{Role of heterotrophic $\mathrm{CO}_{2}$ fixation in cellular metabolism}

The non-autotrophic uptake of inorganic carbon has been reported for a wide range of organisms from prokaryotes and fungi to vertebrates (Wood and Werkman, 1938; Kleiber et al., 1952; Cochrane, 1958; Hartman et al., 1972; Perez and Matin, 1982; Schinner et al., 1982; Parkinson et al., 1990; Roslev et al., 2004; Hesselsoe et al., 2005; Feisthauer et al., 2008; Spona-Friedl et al., 2020) and plants (Melzer and O'Leary, 1987). Currently, more than 20 carboxylases are known, forming an integral part of the central and peripheral metabolic pathways of heterotrophic metabolism (Fig. 1), e.g., in gluconeogenesis, the synthesis of fatty acids, amino acids, vitamins and nucleotides, the assimilation of leucine, and anaplerosis (Evans and Slotin, 1940; Krebs, 1941; Wood and Werkman, 1941; Werkman and Wood, 1942; Kornberg and Krebs, 1957; Wood and Stjernholm, 1962; Kornberg, 1965; Scrutton, 1971; Hartman and Keen, 1973; Dijkhuizen and Harder, 1984; Parkinson et al., 1991; Attwood, 1995; Han et al., 2000; Sauer and Eikmanns, 2005; Erb et al., 2009; Schink, 2009; Erb, 2011; Bar-Even et al., 2012). Carboxylation in heterotrophs not just compensates for the dependence on organic matter, but rather $\mathrm{CO}_{2}$ fulfills the role of a "cosubstrate", providing an effective and simple way to extend an existing organic carbon substrate by a single $\mathrm{C} 1$ unit as part of the secondary production (Erb, 2011).

The most important $\mathrm{CO}_{2}$ fixation pathway in all organisms is anaplerosis. Anaplerosis replenishes intermediates in the tricarboxylic acid (TCA) cycle, which have been released for biosynthesis. TCA metabolites are used as building blocks for macromolecular compounds, e.g. almost half of all amino acids in prokaryotes are directly synthesized from oxaloacetate and $\alpha$-ketoglutarate (Fuchs, 1999). For this purpose, heterotrophs use the enzymes pyruvate carboxylase present in a large variety of organisms, including prokaryotes, archaea, yeasts, fungi, and higher organisms (e.g. mammals), and phosphoenol pyruvate (PEP) carboxylase, widely distributed in bacteria (Attwood, 1995; Jitrapakdee and Wallace, 1999; Sauer and Eikmanns, 2005; Jitrapakdee et al., 2008) (Fig. 1). The replenishment of metabolites continuously withdrawn from the TCA cycle via the anaplerotic reaction of PEP carboxylase entails an assimilation of $\mathrm{CO}_{2}$ corresponding to $25 \%$ of the initial substrate's carbon content. In a systematic stable isotope labeling experiment with Bacillus subtilis, a gram-positive heterotrophic bacterium widespread in the environment, the interdependency of pathways and rates of $\mathrm{CO}_{2}$ fixation on the concurrent utilization of organic substrate(s) was explored (Spona-Friedl et al., 2020). Over the course of the experiments B. subtilis assimilated $6 \%$ and $5 \%$ of carbon biomass from the external $\mathrm{H}^{13} \mathrm{CO}_{3}$ pool when growing on glucose and lactate, respectively (Spona-Friedl et al., 2020). Growth on malate, an intermediate of the TCA cycle, expected to serve directly to refill the oxaloacetate pool of the TCA cycle, still revealed a contribution to biomass production from inorganic carbon of $3 \%$ (Spona-Friedl et al., 2020). In fact, PEP carboxylase was still actively transforming pyruvate to oxaloacetate. Heterotrophic $\mathrm{CO}_{2}$ fixation continued to a lower extent even in the absence of cell growth during the stationary phase (Spona-Friedl et al., 2020), indicating that anaplerotic reactions are important in low-productivity habitats (see below).

Overall, heterotrophic $\mathrm{CO}_{2}$ fixation via anaplerosis in microorganisms contributes around $1 \%$ to $8 \%$ to the carbon biomass (Romanenko, 1964; Perez and Matin, 1982; Doronina and Trotsenko, 1984; Miltner et al., 2004; Roslev et al., 2004; Hesselsoe et al., 2005; Šantrůčková et al., 2005; Feisthauer et al., 2008; Akinyede et al., 2020; Spona-Friedl et al., 2020). Under particular environmental conditions even higher contributions were reported (Perez and Matin, 1982). The advantage that $\mathrm{CO}_{2}$ is readily available to the cell either as atmospheric gas or, more commonly, in its hydrated form $\mathrm{HCO}_{3}^{-}$obviously outcompetes the disadvantage that carboxylation is generally an endergonic reaction (Faber et al., 2015). This thermodynamic obstacle may be less important when carboxylation supports the assimilation of organic substrates more reduced than the organism's biomass, resulting in carbon-limited but excess-energy conditions (Heijnen and Roels, 1981; Ensign et al., 1998; von Stockar et al., 2006; Battley, 2013). In this case, in addition to anaplerosis further carboxylation reactions are induced (Fig. 1) to add oxidized $\mathrm{C}$ (from $\mathrm{CO}_{2}$ ) to the reduced organic substrate for adjusting the degree of reduction to that of the biomass (Fig. 2). For example, the assimilation of leucine and propionate into biomass entails carboxylation of the initial C-6 and C-3 carbon bodies, respectively, and thus triggers an assimilation of dissolved inorganic carbon (DIC) that corresponds to $17 \%$ and $33 \%$ of the initial substrate's carbon content, respectively (Erb, 2011). In aerobic methane oxidation, the full oxidation potential of one molecule of $\mathrm{CO}_{2}$ is needed to adjust the high degree of reduction of methane to that of biomass during its assimilation. Consequently, methanotrophs derive up to $50 \%$ of their carbon biomass from $\mathrm{CO}_{2}$ (Strong et al., 2015; Battley, 2013).

Besides the degree of reduction of organic carbon sources, the partial pressure of $\mathrm{CO}_{2}$ plays a role. Carboxylases may catalyze carboxylation as well as decarboxylation of organic compounds, and the equilibrium of the reaction depends on the concentrations of all compounds involved. An increase in the $\mathrm{CO}_{2}$ concentration may move the equilibrium of the reaction toward the product of the carboxylation, and thus lead to an increase in $\mathrm{CO}_{2}$ fixation.

In a physiological context, the amount of inorganic carbon fixed by heterotrophs, from either an endogenous or ex- 


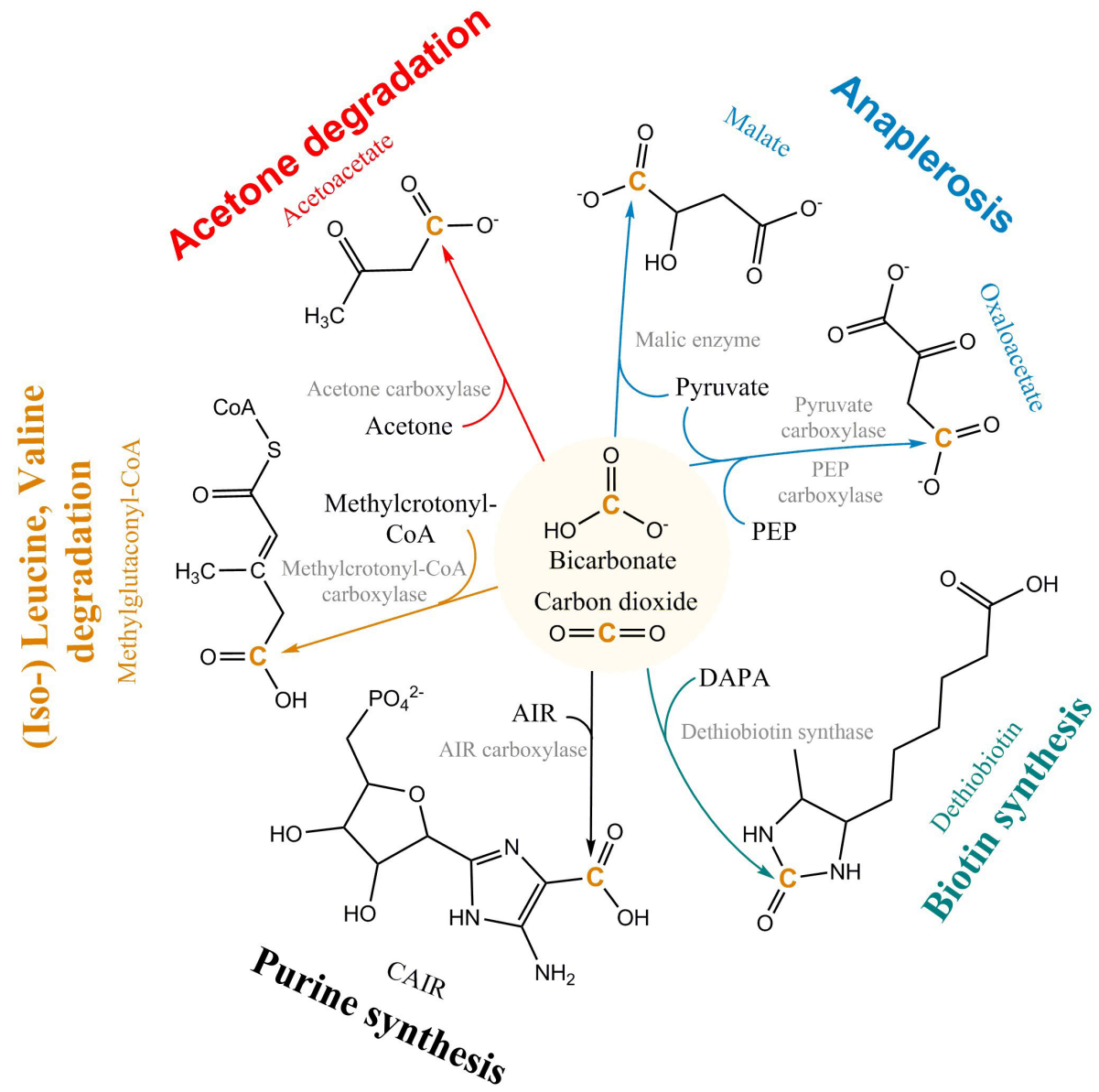

Figure 1. Selected heterotrophic $\mathrm{CO}_{2}$ fixation reactions and pathways. PEP: phosphoenolpyruvate; DAPA: 7,8-diaminononanoate; AIR: 1-(5'-phosphoribosyl)-5-aminoimidazole; CAIR: 1-(5-phospho-D-ribosyl)-5-amino-4-imidazolecarboxylate; CoA: Coenzyme-A

ogenous source, may be dependent on the metabolic state of the organisms and the specific environmental conditions. In their early work, Romanenko et al. (1972) suggested that the rate of heterotrophic anaplerotic fixation of DIC is strictly proportional to the heterotrophic bacterial carbon production. Since then, a number of factors have been identified potentially influencing the relative contribution of anaplerotic and other non-autotrophic $\mathrm{CO}_{2}$ fixation reactions on biomass production. In laboratory experiments with the bacterial strain Thiobacillus novellus, for example, a higher amount of $\mathrm{CO}_{2}$ was fixed under nutrient-limited conditions (Perez and Matin, 1982). Moreover, mixotrophic bacterial strains fixed more DIC compared to those grown autotrophically (Perez and Matin, 1982). Fungi fixed relatively more $\mathrm{CO}_{2}$ at lower organic carbon (glucose and maltose) concentrations (Schinner et al., 1982). In conclusion, the degree of heterotrophic $\mathrm{CO}_{2}$ fixation highly depended on the availability of easily degradable organic carbon sources (Schinner et al., 1982).

Studies on the possible relationship between heterotrophic DIC fixation and the activity of prokaryotic cells revealed contradicting results. While Roslev et al. (2004) mentioned actively growing cells fix more DIC than resting cells, Merlin et al. (2003) report enhanced uptake of DIC by heterotrophic bacteria during slow growth and starvation. A relationship between DIC and heterotrophic bacterial production has been reported frequently as exemplified below.

\section{Respiration and non-autotrophic $\mathrm{CO}_{2}$ fixation}

The production of $\mathrm{CO}_{2}$ via respiration and the parallel fixation of $\mathrm{CO}_{2}$ in heterotrophs take place simultaneously. The heterotrophic fixation of $\mathrm{CO}_{2}$ is thus generally considered a back-reaction; i.e., part of the originally produced $\mathrm{CO}_{2}$ from respiration is re-assimilated. Following this line of arguments, the more reduced an organic substrate is the less $\mathrm{CO}_{2}$ is released (Fig. 2). The heterotrophic fixation of DIC does not necessarily lead to a net carbon biomass production; however, if microbes oxidize geogenic methane, this would result in a net carbon biomass production. Experimentally it is difficult to differentiate respiratory $\mathrm{CO}_{2}$ flux from concurrent anaplerotic $\mathrm{CO}_{2}$ fixation. As a consequence, there 


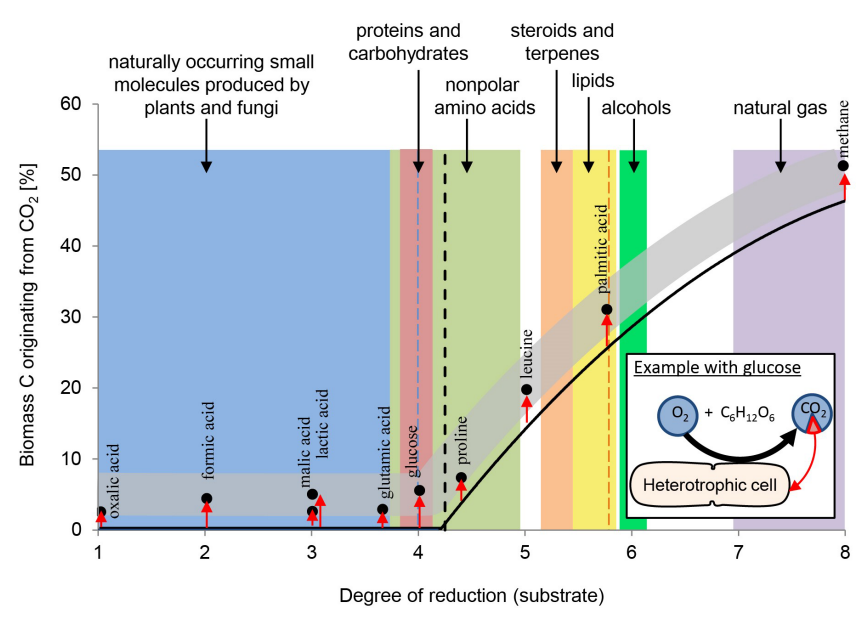

Figure 2. Anaplerotic $\mathrm{CO}_{2}$ fixation contributes $1 \%-8 \%$ of carbon biomass (indicated by the grey band) in heterotrophic cells. Dependent to the organism and in relation to the uptake of the individual organic compounds and their entry into the TCA cycle and central metabolic pathways the relative amount of inorganic carbon assimilated varies, as highlighted by the red arrows. See examples for malic and lactic acid. With organic carbon sources more reduced than the organism's biomass (dashed line) further carboxylation reactions are induced (indicated by black line), increasing the overall carbon contribution from $\mathrm{CO}_{2}$ beyond anaplerosis (grey band). In methanotrophs, $50 \%$ of the cell's carbon may originate from $\mathrm{CO}_{2}$ fixation. For further explanations, see text.

are numerous experiments and field studies determining dark $\mathrm{CO}_{2}$ fixation, but only a few studies quantified the assimilation of DIC by non-autotrophs.

Respiration in aquatic systems is frequently determined via the consumption of dissolved oxygen (Robinson and Williams, 2005), potentially underestimating the carbon use efficiency of heterotrophs. Depending on the substrate, the respiration quotient $\left(\Delta \mathrm{CO}_{2} /-\Delta \mathrm{O}_{2}\right)$ varies between $0.7-1.3$ (Robinson, 2019), leading to an error between $20 \%$ and $40 \%$ with regard to $\mathrm{CO}_{2}$ production from respiration. Moreover, the respiration quotient also varies because other oxygenconsuming processes are potentially taking place simultaneously (e.g. nitrification) (Robinson, 2019). For instance, it is $138 \mathrm{O}_{2}$ for $106 \mathrm{CO}_{2}$ for ideal Redfield-type organic matter and $150 \mathrm{O}_{2}$ for $106 \mathrm{CO}_{2}$ for more realistic marine organic matter (Fraga et al., 1998; Paulmier et al., 2009). Calculations based on a study on temperate forest soils revealed a reduction of overall $\mathrm{CO}_{2}$ emissions due to dark $\mathrm{CO}_{2}$ fixation by mainly heterotrophic microbes (Akinyede et al., 2020). Collectively, with respect to $\mathrm{C}$ cycling, heterotrophic $\mathrm{CO}_{2}$ fixation and the carbon flux from the inorganic pool into heterotrophic biomass can be regarded as a process more important than hitherto assumed.

\section{$4 \mathrm{CO}_{2}$ fixation in habitats dominated by heterotrophs}

In contrast to sunlit habitats, where photoautotrophs make up a significant portion of the total biomass and photosynthesis is of major importance in carbon cycling, heterotrophs and chemolithoautotrophs represent the prevailing biota in the "dark habitats", i.e., soils, subsurface environments, and the deep sea. These dark environments, although characterized by disproportionally lower biological activity, exceed their photic counterparts in both volume and biomass. In the oceans, the deep sea (below $200 \mathrm{~m}$ ) exceeds the sunlit surface layer by a factor of 18 in volume and, remarkably, by a factor of 2 in biomass (Arístegui et al., 2009). Therefore, the so-called "dark $\mathrm{CO}_{2}$ fixation" not only occurs in specific "hot spots" on the seafloor (hydrothermal vents, cold seeps, and mud volcanoes), or in anoxic waters, but also throughout the entire oxygenated "dark" water column (Reinthaler et al., 2010; Yakimov et al., 2014). In limnic environments, the dark groundwater ecosystems outnumber surface waters 100-fold in terms of water volume (Danielopol et al., 2003), and similarly, soils are also, with the exception of their surface, exclusively dark habitats.

Yet, heterotrophic $\mathrm{CO}_{2}$ fixation does not occur only in the dark environments since heterotrophs are also found in the photic zone. This is particularly relevant in the ocean because the photic zone is where the highest biomass concentrations are found. Recently, it has been estimated that the inclusion of dark $\mathrm{CO}_{2}$ fixation (integrated over the euphotic layer, 0 $150 \mathrm{~m}$ depth) would increase oceanic primary production estimates by $2.5 \%-22 \%$ (Baltar et al., 2019). A similar situation might be assumed for surface inland waters; however, global estimations are missing so far.

Dark DIC fixation has been reported for all types of ecosystems, including marine habitats (Wuchter et al., 2003; Middelburg, 2011; DeLorenzo et al., 2012; Molari et al., 2013; Baltar and Herndl, 2019; Lengger et al., 2019; Smith et al., 2019; Vasquez-Cardenas et al., 2020), brackish and freshwater systems (Bräuer et al., 2013; Santoro et al., 2013; Noguerola et al., 2015; Signori et al., 2017; Vick-Majors and Priscu, 2019; Zhao et al., 2020), cave waters and groundwater ecosystems (Pedersen and Ekendahl, 1992a, b; Kotelnikova and Pedersen, 1998; Kellermann et al., 2012; Lazar et al., 2017), and soil habitats (Ehleringer et al., 2000; Miltner et al., 2004, 2005; Šantrǔčková et al., 2005, 2018; Akinyede et al., 2020, and references therein). In the absence of solar radiation, particularly in the dark ocean, $\mathrm{CO}_{2}$ fixation rates of up to $\sim 125 \mathrm{mg} \mathrm{C} \mathrm{m}^{-3} \mathrm{~d}^{-1}$ have been measured, amounting to $30 \%$ (on a per volume basis) of the phototrophic $\mathrm{CO}_{2}$ fixation in ocean surface waters (Zopfi et al., 2001; Detmer et al., 1993; Casamayor et al., 2001; Baltar et al., 2010). In a eutrophic lagoon, dark DIC fixation accounted for $31 \%$ of total DIC fixation in the water column (Lliros et al., 2011). Recently it was shown that the ratio between dark / light $\mathrm{CO}_{2}$ fixation in oceanic surface waters which is usually around 0.1 increases with depth, reaching a ratio of 
1 at $120-160 \mathrm{~m}$ depth (Baltar et al., 2019). In the past, however, dark DIC fixation has frequently been attributed to the activity of chemoautotrophs only. Only a few studies so far have provided strong quantitative evidence for heterotrophic $\mathrm{CO}_{2}$ fixation in aquatic and terrestrial ecosystems (Table 1).

As indicated, part of the dark $\mathrm{CO}_{2}$ fixation in oceans has been attributed to chemolithoautotrophic archaea (Wuchter et al., 2003; Ingalls et al., 2006), obtaining the energy required for the endergonic carboxylation through the oxidation of reduced inorganic compounds, such as ammonia or hydrogen sulfide (Swan et al., 2011; Zhang et al., 2020). A total annual chemolithoautotrophic $\mathrm{CO}_{2}$ fixation rate of $0.77 \mathrm{PgC}$ was calculated for the oceans (Middelburg, 2011). The observed fluxes of the reduced inorganic compounds available as energy sources, however, seem largely insufficient to explain the relatively high dark $\mathrm{CO}_{2}$ fixation rates (Overbeck, 1979; Tuttle and Jannasch, 1979; Baltar et al., 2010; Reinthaler et al., 2010; Herndl and Reinthaler, 2013). In some cases, the supply rates of the reduced inorganic compounds used as an energy source explain less than $40 \%$ of the observed dark $\mathrm{CO}_{2}$ fixation rates (Zopfi et al., 2001). Recently, chemoautotrophic nitrification was estimated to explain $<13 \%$ of the dark $\mathrm{CO}_{2}$ fixation (integrated over the euphotic zone), with the rest coming from either heterotrophic DIC fixation or other chemoautotrophic processes (Baltar and Herndl, 2019).

The potential energy sources for the unexplained proportion of the dark $\mathrm{CO}_{2}$ fixation remain enigmatic. Possible explanations could be either an underestimation of the supply rates of reduced inorganic compounds or the uptake of $\mathrm{CO}_{2}$ by heterotrophic organisms (Zopfi et al., 2001; Baltar et al., 2019). In the surface ocean in particular, DIC incorporation via anaplerotic reactions might play an important role in compensating for metabolic imbalances in marine bacteria under oligotrophic conditions, contributing $>30 \%$ of the carbon incorporated into biomass (González et al., 2008; Palovaara et al., 2014). Evidence for the latter comes from experiments with Arctic seawater, which exhibited high DIC fixation rates $\left(0.5-2.5 \mu \mathrm{g} \mathrm{C} \mathrm{L}-1 \mathrm{~d}^{-1}\right)$ correlating with heterotrophic bacterial production (Alonso-Sáez et al., 2010). Using different molecular tools, DIC uptake was attributed mainly to heterotrophic Gamma- and Betaproteobacteria rather than to typical chemoautotrophs, thus showing that chemolithoautotrophs were not the main drivers of $\mathrm{CO}_{2}$ fixation in this habitat (Alonso-Sáez et al., 2010). Further evidence comes from the genome of Polaribacter sp. MED152, a representative of Bacteroidetes, which typically comprise about $10 \%-20 \%$ of the prokaryotic abundance in seawater (González et al., 2008). A unique combination of membrane transporters and carboxylases in these organisms indicates the importance of anaplerosis in addition to other DIC fixation pathways (González et al., 2008). If the heterotrophic metabolism of bacteria is suddenly intensified (e.g., after an input of organic matter), dark DIC fixation rates and the expression of transcripts associated with key anaplerotic enzymes increase proportionally (Baltar et al., 2016). As men- tioned above, contradicting results were obtained on the relationship between heterotrophic $\mathrm{CO}_{2}$ fixation and the availability of organic matter. A few studies suggest a relative increase in dark DIC fixation in oligotrophic habitats harboring slow-growing or starving bacterial populations (Perez and Matin, 1982; Schinner et al., 1982; Merlin et al., 2003; Alonso-Sáez et al., 2010; Santoro et al., 2013). Considering the slow community-wide specific growth rates of heterotrophic bacteria in oligotrophic and/or cold waters, such as the marine aphotic zone, the Arctic Ocean, deep sea sediments, groundwater systems and the terrestrial subsurface, alpine limnic systems, and deep-lake sediments, enhanced anaplerotic DIC uptake can be expected. However, there is also evidence for the stimulation of dark DIC fixation in response to organic matter enrichment in different types of soils (Miltner et al., 2005; Šantrůčková et al., 2018). Hence, these contradictory findings require further, more systematic research.

Other environmental factors that may influence dark DIC fixation include the concentrations of $\mathrm{CO}_{2}$ and bicarbonate as inorganic carbon sources. An increase in the $\mathrm{CO}_{2}$ concentration may shift the equilibrium of the carboxylationdecarboxylation reactions increasing $\mathrm{CO}_{2}$ fixation. Elevated partial pressure of $\mathrm{CO}_{2}$ might stimulate dark DIC fixation. In temperate forest soils, rates of dark microbial $\mathrm{CO}_{2} \mathrm{fix}-$ ation were positive correlated with the $\mathrm{CO}_{2}$ concentration (Spohn et al., 2019). Similarly, with increasing $\mathrm{CO}_{2}$ concentrations, higher dark DIC fixation was observed in wetland soils affected by subcrustal $\mathrm{CO}_{2}$ degassing (Beulig et al., 2015). Here, besides known chemoautotrophs, $\mathrm{CO}_{2}$ fixation via anaplerotic reactions was shown for putatively heterotrophs, i.e., subdivision 1 Acidobacteriaceae, lacking enzymatic pathways for autotrophic $\mathrm{CO}_{2}$ fixation (Beulig et al., 2015). In experiments with two marine heterotrophic bacterial isolates, elevation of $\mathrm{CO}_{2}$ concentration provoked an increase in $\mathrm{CO}_{2}$ fixation along with a decrease in respiration (Teiro et al., 2012). Thus, we may assume that a rise in $\mathrm{CO}_{2}$ concentrations and $\mathrm{CO}_{2}$-induced geochemical changes will alter carbon turnover in affected ecosystems, with dark DIC fixation and anaplerotic reactions becoming more important.

\section{Quantitative estimates of heterotrophic $\mathrm{CO}_{2}$ fixation in different environments}

\subsection{Quantification of heterotrophic DIC fixation}

It is difficult to properly quantify heterotrophic fixation of inorganic carbon in the environment. Not surprisingly, quantitative data almost exclusively originate from laboratory experiments using cultures and tissues in combination with carbon isotopic labeling (e.g. Spona-Friedl et al., 2020). Field studies generally report on dark carbon fixation, including the activity of chemoautotrophs and heterotrophs. So far, evidence for the significant contribution of heterotrophic $\mathrm{CO}_{2}$ 


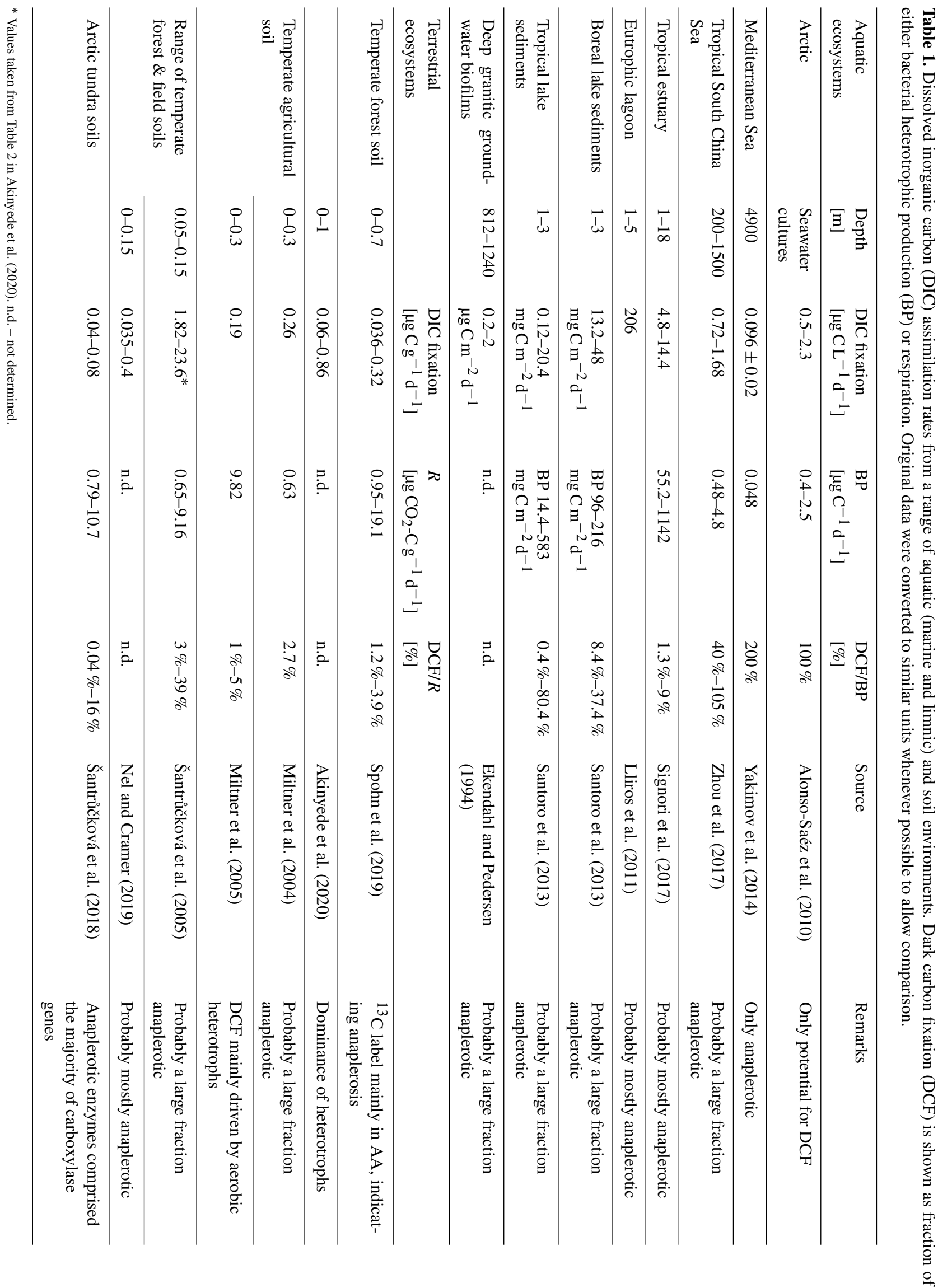


fixation, as highlighted for selected studies in Table 1, is based on additional measures complementing the quantification of dark carbon fixation, i.e. molecular microbial community analysis occasionally including the quantitative assessment of functional genes involved in carbon fixation and characterization of environmental conditions. In fact, significant dark carbon fixation (i) in the obvious absence of chemoautotrophs and related genes or (ii) in well-oxygenated environments that lack potential electron donors (e.g. $\mathrm{H}_{2}$, $\mathrm{H}_{2} \mathrm{~S}, \mathrm{NH}_{4}$ ) led authors to conclude on the quantitative importance of heterotrophic carbon fixation (e.g. Miltner et al., 2005; Alonso-Saéz et al., 2010; Yakimov et al., 2014; Šantrůčková et al., 2018; Akinyede et al., 2020). Individual studies succeeded to follow the label of inorganic carbon in environmental samples into amino acids of microorganisms (Spohn et al., 2019; Spona-Friedl et al., 2020). In the future, the combined application of metabolomics and isotope tracing may help further develop this field of research.

\subsection{Heterotrophic $\mathrm{CO}_{2}$ fixation in different habitats}

Measurements of dark DIC fixation with strong evidence of a significant contribution of heterotrophic assimilation of DIC are scarce. In Table 1, we provide a compilation of studies conducted in soils and marine and limnic ecosystems. Where possible, we compared dark DIC fixation rates with heterotrophic activity. In marine and limnic systems, heterotrophic carbon production as a widely applied activity measurement was used. In soils, we compared dark DIC fixation rates with respiration, i.e., $\mathrm{CO}_{2}$ production. Dark DIC fixation rates in different marine systems range between 0.1 and $206 \mu \mathrm{g} \mathrm{C} \mathrm{L}-1 \mathrm{~d}^{-1}$, with the highest values found in a eutrophic lagoon and the lowest values in the deep waters of the Mediterranean Sea (Table 1). Data from limnic systems originate from lake sediments with dark DIC fixation rates between 0.12 and $48 \mathrm{mg} \mathrm{C} \mathrm{m}^{-2} \mathrm{~d}^{-1}$ (Table 1). Projecting these numbers to only the top $10 \mathrm{~cm}$ of sediment in the different lakes studied (which is a gross simplification), values of $1.2-480 \mu \mathrm{g} \mathrm{CL}^{-1}$ sediment per day are obtained. When compared to rates of bacterial carbon production, dark DIC fixation rates in these habitats accounted for a considerable fraction of total carbon assimilation, occasionally even exceeding it (Table 1). In soils, the dark DIC fixation rates, which were attributed mainly to the activity of heterotrophs, amounted to $0.04 \%-39 \%$ of the overall respiration rate (Table 1). Dark DIC fixation rates range from $36 \mathrm{ng} \mathrm{C}$ to $23.6 \mu \mathrm{g} \mathrm{C} \mathrm{g}^{-1} \mathrm{~d}^{-1}$ covering 3 orders of magnitude (Table 1). The contribution of heterotrophically fixed DIC to biomass carbon of microbes ranged from $0.2 \%-1.1 \%$ in temperate forest soil (Akinyede et al., 2020), $0.2 \%-4.6 \%$ in temperate forest and field soils (Šantrůčková et al., 2005), to $7 \%$ in arable soil (Miltner et al., 2004). Šantrůčková et al. (2005) estimated the overall heterotrophic $\mathrm{CO}_{2}$ fixation to be even higher, i.e., $1.9 \%-11.3 \%$ taking into account that the labile fraction of the biodegradable organic carbon re- sulted from metabolites released by spilling reactions of microorganisms due to a limitation in inorganic nutrients or due to the presence of highly reduced energy-rich carbon sources (e.g. Tempest and Neijssel, 1992). A contribution of heterotrophic $\mathrm{CO}_{2}$ fixation to biomass carbon of $6.5 \pm 2.8 \%$ was found in drinking water biofilms and activated sludge (Roslev et al., 2004).

\subsection{Carbon biomass stock originating from heterotrophic $\mathrm{CO}_{2}$ fixation}

While it is difficult to derive global estimations from the few studies that measured heterotrophic $\mathrm{CO}_{2}$ fixation rates in marine, limnic, and terrestrial ecosystems, we may use a conservative approach assuming that at least $1 \%-5 \%$ of carbon biomass of all heterotrophs originates from anaplerotic DIC fixation. Earth's total living biomass is estimated to amount to about $499-738 \mathrm{PgC}$, of which approx. 451-653 Pg C is photoautotrophic biomass (Bar-On et al., 2018). Heterotrophic biomass thus contributes $47-85 \mathrm{Pg} \mathrm{C}$ (Table S1 in the Supplement). The uncertainties of the estimates of heterotrophic biomass of the terrestrial subsurface, however, are high (Whitman et al., 1998; McMahon and Parnell, 2014; Bar-On et al., 2018). Nevertheless, following this line of evidence, anaplerotic $\mathrm{CO}_{2}$ fixation contributes between $0.5-$ $5 \mathrm{Pg} \mathrm{C}$ to the living biomass.

\subsection{Carbon flux related to heterotrophic $\mathrm{CO}_{2}$ fixation}

In terms of annual global heterotrophic production rates, oceans and the terrestrial subsurface (including soils) are the main habitats of heterotrophic $\mathrm{CO}_{2}$ fixation (Cole et al., 1988; Magnabosco et al., 2018) (Table S2). Recently, Akinyede et al. (2020) estimated a global dark $\mathrm{CO}_{2}$ fixation rate of all temperate forest soils of $0.26 \pm 0.07 \mathrm{PgC}^{-1}$. We calculated a global heterotrophic $\mathrm{C}$ production of 34$245 \mathrm{Pg} \mathrm{Cyr}^{-1}$, which would translate into $0.34-12.3 \mathrm{Pg}$ of DIC bound by heterotrophic $\mathrm{CO}_{2}$ fixation each year. Interestingly, these numbers are consistent with the recently calculated contribution of $\mathrm{CO}_{2}$ fixation for the integrated epipelagic ocean of ca. 1.2-11 $\mathrm{Pg} \mathrm{C} \mathrm{yr}^{-1}$ (Baltar and Herndl 2019). This is a significant carbon flux amounting to $0.3 \%-$ $14 \%$ of the global net amount of carbon produced annually by photoautotrophs (90-110 $\mathrm{Pg} \mathrm{C} \mathrm{yr}^{-1}$; Ciais et al., 2013).

Our estimates, as said, are subject to a high uncertainty, which, on the one hand, results from the dependency of the extent of heterotrophic $\mathrm{CO}_{2}$ fixation on the organic carbon oxidized and, on the other hand, on the predominant environmental conditions. Moreover, data on terrestrial and marine subsurface environments, although large in dimension, are scarce. For these environments, no detailed information on the abundance, growth (yield), and metabolic activity of microbial communities is available, particularly with increasing depth. Most of the deeper subsurface environments, even when harboring considerable living biomass, do not 
participate in the global carbon cycle on short and medium timescales (years to decades), but rather on centennial to geological timescales. Nevertheless, in order to provide a first estimate and to be able to roughly evaluate the relevance of heterotrophic $\mathrm{CO}_{2}$ fixation for all habitats, we adopted this conservative approach (see also Tables S1 and S2).

\section{Conclusions}

Current models of carbon cycling and carbon sequestration (Gruber et al., 2004; Le Quéré et al., 2009) do not account for heterotrophic $\mathrm{CO}_{2}$ fixation. Despite the uncertainties in the data on heterotrophic biomass and production rates for some habitats (e.g. the terrestrial subsurface), the numbers presented here represent the first attempt to quantify the global contribution and relevance of heterotrophic $\mathrm{CO}_{2}$ fixation to carbon cycling. Our results indicate that heterotrophs significantly contribute to global $\mathrm{CO}_{2}$ fixation - especially (although not restricted to) in habitats experiencing elevated $\mathrm{CO}_{2}$ concentrations and/or lacking a sufficient supply of degradable organic carbon. In specific environments, this may explain the mismatch between autotrophic $\mathrm{C}$ input, consumption, and sequestration as has been observed in marine systems (Baltar and Herndl, 2019; Burd et al., 2010; Reinthaler et al., 2010; Morán et al., 2007; Hoppe et al., 2002; Tait and Schiel, 2013). Particularly in aphotic habitats (which outnumber the photic habitats in both size and volume) such as the dark ocean, subseafloor sediments, soils, and the sediments and rocks of the terrestrial subsurface (Miltner et al., 2004, 2005; Yakimov et al., 2014; Wegener et al., 2012), carbon cycling needs to be re-evaluated taking into account anaplerotic $\mathrm{CO}_{2}$ fixation and other inorganic carbon uptake pathways in heterotrophs. In subseafloor sediments, wetlands, and marshes, as well as in other habitats where methane oxidation is a key process, a large fraction $(10 \%-50 \%)$ of heterotrophic biomass potentially originates from heterotrophic DIC fixation. Recently, a timeseries study showed a tendency towards higher ratios of dark to light DIC fixation in the top half of the euphotic layer (0$65 \mathrm{~m}$ ) in the years 2012-2019 than in the preceding years (data started in 1989), which was linked to oceanographic changes (i.e., a deepening of the mixed zone) (Baltar et al., 2019). Moreover, the metabolic theory of ecology posits that heterotrophic metabolism increases more than gross primary production in the ocean in response to warming (see Baltar et al., 2019, and reference therein), which might also make heterotrophic DIC fixation relatively more important in a warmer ocean. In light of global warming leading to an extensive thawing of permafrost soils and providing new habitats for methanotrophs, these processes are expected to become more important in the future. Hence, the potential contribution of heterotrophic $\mathrm{CO}_{2}$ fixation under climate change conditions clearly deserves further investigation.
Data availability. All data that have been used for our calculations are available in Tables S1 and S2 in the Supplement. No further data sets were used in this article.

Supplement. The supplement related to this article is available online at: https://doi.org/10.5194/bg-18-3689-2021-supplement.

Author contributions. AB, ME, and CG conceived the idea for the manuscript. $\mathrm{AB}, \mathrm{GJH}$, and $\mathrm{CG}$ wrote the manuscript. MSF, ME, MA, FB, and TR substantially commented on and edited the manuscript. MA, MSF, and CG did the literature search on available global carbon data. CG and MA performed the estimation of heterotrophic $\mathrm{CO}_{2}$ fixation on a global scale.

Competing interests. The authors declare that they have no conflict of interest.

Acknowledgements. We acknowledge Bo Barker Jørgensen for commenting on an earlier draft of the manuscript. We thank Rudolf K. Thauer and Wolfgang Eisenreich for fruitful discussions on heterotrophic $\mathrm{CO}_{2}$ fixation.

Financial support. Financial support was provided by the Wittgenstein Prize (Austrian Science Fund, project number Z194-B17), by the European Research Council under the European Community's Seventh Framework Program (FP7/2007-2013)/ERC grant agreement no. 268595 (MEDEA project), and the Austrian Science Fund (P 28781-B21) to Gerhard J. Herndl. Financial support was further provided by the Helmholtz Center Munich to Alexander Braun, Martin Elsner, Marina Spona-Friedl, and Christian Griebler.

Review statement. This paper was edited by Steven Bouillon and reviewed by two anonymous referees.

\section{References}

Akinyede, R., Taubert, M., Schrumpf, M., Trumbore, S., and Küsel, $\mathrm{K}$.: Rates of dark $\mathrm{CO}_{2}$ fixation are driven by microbial biomass in a temperate forest soil, Soil Biol. Biochem., 150, 107950, https://doi.org/10.1016/j.soilbio.2020.107950, 2020.

Alonso-Sáez, L., Galand, P. E., Casamayor, E. O., Pedrós-Alió, C., and Bertilsson, S.: High bicarbonate assimilation in the dark by Arctic bacteria, ISME J., 4, 1581-1590, 2010.

Arístegui, J., Gasol, J. M., Duarte, C. M., and Herndl, G. J.: Microbial oceanography of the dark ocean's pelagic realm, Limnol. Oceanogr., 54, 1501-1529, 2009.

Attwood, P. V.: The structure and the mechanism of action of pyruvate-carboxylase, Int. J. Biochem. Cell B, 27, 231-249, 1995.

Baltar, F. and Herndl, G. J.: Ideas and perspectives: Is dark carbon fixation relevant for oceanic primary production estimates?, 
Biogeosciences, 16, 3793-3799, https://doi.org/10.5194/bg-163793-2019, 2019.

Baltar, F., Arístegui, J., Sintes, E., Gasol, J. M., Reinthaler, T., and Herndl, G. J.: Significance of non-sinking particulate organic carbon and dark $\mathrm{CO}_{2}$ fixation to heterotrophic carbon demand in the mesopelagic northeast Atlantic, Geophys. Res. Lett., 37, 16, 2010.

Baltar, F., Lundin, D., Palovaara, J., Lekunberri, I., Reinthaler, T., Herndl, G. J., and Pinhassi, J.: Prokaryotic responses to ammonium and organic carbon reveal alternative $\mathrm{CO}_{2}$ fixation pathways and importance of alkaline phosphatase in the mesopelagic North Atlantic, Front. Microbiol., 7, 1670, https://doi.org/10.3389/fmicb.2016.01670, 2016.

Baltar, F., Bayer, B., Bednarsek, N., Deppeler, S., Escribano, R., Gonzalez, C. E., Hansman, R. L., Mishra, R. K., Moran, M. A., Repeta, D. J., Robinson, C., Sintes, E., Tamburini, C., Valentin, L. E., and Herndl, G. J.: Towards integrating evolution, metabolism, and climate change studies of marine ecosystems, Trends Ecol. Evol., 34, 1022-1033, 2019.

Bar-Even, A., Noor, E., and Milo, R.: A survey of carbon fixation pathways through a quantitative lens, J. Exp. Bot., 63, 23252342, 2012.

Bar-On, Y. M., Phillips, R., and Milo, R.: The biomass distribution on Earth, P. Natl. Acad. Sci. USA, 115, 6506-6511, 2018.

Battley, E. H.: A theoretical study of the thermodynamics of microbial growth using Saccharomyces cerevisiae and a different free energy equation, Q. Rev. Biol., 88, 69-96, 2013.

Beer, C., Reichstein, M., Tomelleri, E., Ciais, P., Jung, M., Carvalhais, N., Rödenbeck, C., Arain, M. A., Baldocchi, D., Bonan, G. B., Bondeau, A., Cescatti, A., Lasslop, G., Lindroth, A., Lomas, M., Luyssaert, S., Margolis, H., Oleson, K. W., Roupsard, O., Veenendaal, E., Viovy, N., Williams, C., Woodward, F. I., and Papale, D.: Terrestrial gross carbon dioxide uptake: global distribution and covariation with climate, Science, 329, 834-838, 2010.

Berg, I. A.: Ecological aspects of the distribution of different autotrophic $\mathrm{CO}_{2}$ fixation pathways, Appl. Environ. Microbiol., 77, 1925-1936, 2011.

Berg, I. A., Kockelkorn, D., Buckel, W., and Fuchs, G.: A 3hydroxypropionate/4-hydroxybutyrate autotrophic carbon dioxide assimilation pathway in Archaea, Science, 318, 1782-1786, 2007.

Beulig, F., Heuer, V. B., Akob, D. M., Viehweger, B., Elvert, M., Herrmann, M., Hinrichs, K.-U., and Küsel, K.: Carbon flow from volcanic $\mathrm{CO}_{2}$ into soil microbial communities of a wetland mofette, ISME J., 9, 746-759, 2015.

Bräuer, S. L., Kranzler, K., Goodson, N., Murphy, D., Simon, H. M., Baptista, A. M., and Tebo, B. M.: Dark carbon fixation in the Columbia River's estuarine turbidity maxima: molecular characterization of red-type $c b b l$ genes and measurement of DIC uptake rates in response to added electron donors, Estuar. Coast. Shelf S., 36, 1073-1083, 2013.

Burd, A. B., Hansell, D. A., Steinberg, D. K., Anderson, T. R., Arístegui, J., Baltar, F., Beaupre, S. R., Buesseler, K. O., DeHairs, F., Jackson, G. A., Kadko, D. C., Koppelmann, R., Lampitt, R. S., Nagata, T., Reinthaler, T., Robinson, C., Robison, B. H., Tamburini, C., and Tanaka, T.: Assessing the apparent imbalance between geochemical and biochemical indicators of meso-and bathypelagic biological activity: What the @\$\#! is wrong with present calculations of carbon budgets?, Deep-Sea Res. Pt. II, 57, 1557-1571, 2010.

Casamayor, E. O., García-Cantizano, J., Mas, J., and Pedrós-Alió, C.: Primary production in estuarine oxic/anoxic interfaces: contribution of microbial dark $\mathrm{CO}_{2}$ fixation in the Ebro River Salt Wedge Estuary, Mar. Ecol.-Prog. Ser., 215, 49-56, 2001.

Ciais, P., Sabine, C., Bala, G., Bopp, L., Brovkin, V., Canadell, J., Chhabra, A., DeFries, R., Galloway, J., Heimann, M., Jones, C., Le Quéré, C., Myneni, R. B., Piao, S., and Thornton, P.: Carbon and other biogeochemical cycles, in: Climate change 2013: The physical science basis. Contribution of working group I to the fifth assessment report of the Intergovernmental Panel on Climate Change, edited by: Stocker, T. F., Qin, D., Plattner, G.-K., Tignor, M., Allen, S. K., Boschung, J., Nauels, A., Xia, Y., Bex, V., and Midgley, P. M., 465-570, Cambridge, United Kingdom and New York, NY, USA, Cambridge University Press, 2013.

Cochrane, V. W.: Physiology of fungi, John Wiley, New York, 1958.

Cole, J. J., Findlay, S. E. G., and Pace, M. L.: Bacterial production in fresh and saltwater ecosystems: a cross-system overview, Mar. Ecol.-Prog. Ser., 43, 1-10, 1988.

Danielopol, D. L., Griebler, C., Gunatilaka, A., and Notenboom, J. Present state and future prospects for groundwater ecosystems, Environ. Conserv., 30, 104-130, 2003.

DeLorenzo, S., Bräuer, S. L., Edgmont, C. A., Herfort, L., Tebo, B. M., and Zuber, P.: Ubiquitous dissolved inorganic carbon assimilation by marine bacteria in the Pacific Northwest Coastal Ocean as determined by stable isotope probing, PLoS ONE, 7, e46695, https://doi.org/10.1371/journal.pone.0046695, 2012.

Detmer, A. E., Giesenhagen, H. C., Trenkel, V. M., Auf dem Venne, H., and Jochem, F. J.: Phototrophic and heterotrophic pico- and nanoplankton in anoxic depths of the central Baltic Sea, Mar. Ecol.-Prog. Ser., 99, 197-203, 1993.

Dijkhuizen, L. and Harder, W.: Current views on the regulation of autotrophic carbon dioxide fixation via the Calvin cycle in bacteria, Antonie van Leeuwenhoek, 50, 473-487, 1984.

Doronina, N. V. and Trotsenko, Y. A.: The levels of carbon dioxide assimilation in bacteria with different pathways of 1-carbon metabolism, Mikrobiologiya, 53, 885-889, 1984.

Ehleringer, J. R., Buchmann, N., and Flanagan, L. B.: Carbon isotope ratios in belowground carbon cycle processes, Ecol. Appl., 10, 412-422, 2000.

Ekendahl, S. and Pedersen, K.: Carbon transformations by attached bacterial populations in granitic ground water from deep crystalline bed-rock of the Stripa research mine, Microbiology, 140, 1565-1573, 1994.

Ensign, S. A., Small, F. J., Allen, J. R., and Sluis, M. K.: New roles for $\mathrm{CO}_{2}$ in the metabolism of aliphatic epoxides and ketones, Arch. Microbiol., 169, 179-187, 1998.

Erb, T. J.: Carboxylases in natural and synthetic microbial pathways, Appl. Environ. Microb., 77, 8466-8477, 2011.

Erb, T. J., Brecht, V., Fuchs, G., Muller, M., and Alber, B. E.: Carboxylation mechanism and stereochemistry of crotonyl-CoA carboxylase/reductase, a carboxylating enoyl-thioester reductase, $\mathrm{P}$. Natl. Acad. Sci. USA, 106, 8871-8876, 2009.

Evans Jr., E. A. and Slotin, L.: The utilization of carbon dioxide in the synthesis of $\alpha$-ketoglutaric acid, J. Biol. Chem., 136, 301$302,1940$. 
Faber, K., Fessner, W. D., and Turner, N. J.: Science of synthesis: biocatalysis in organic synthesis Vol. 2, 672 pp., Georg Thieme, Stuttgart, 2015.

Feisthauer, S., Wick, L. Y., Kastner, M., Kaschabek, S. R., Schlomann, M., and Richnow, H. H.: Differences of heterotrophic ${ }^{13} \mathrm{CO}_{2}$ assimilation by Pseudomonas knackmussii strain B13 and Rhodococcus opacus $1 \mathrm{CP}$ and potential impact on biomarker stable isotope probing, Environ. Microbiol., 10, 1641-1651, 2008.

Fraga, F., Rios, A., Perez, F., and Figueras, F.: Theoretical limits of oxygen:carbon and oxygen : nitrogen ratios during photosynthesis and mineralisation of organic matter in the sea, Mar. Chem., 62, 161-168, 1998.

Fuchs, G.: Biosynthesis of building blocks, in: Biology of the prokaryotes, edited by: Lengeler, J. W., Drews, G., and Schlegel, H. G., 110-160, Thieme, Stuttgart, New York, 1999.

Giovannoni, S. J. and Stingl, U.: Molecular diversity and ecology of microbial plankton, Nature, 437, 343-348, https://doi.org/10.1038/nature04158, 2005.

González, J. M., Fernández-Gómez, B., Fernández-Guerra, A., Gómez-Consarnau, L., Sánchez, O., Coll-Lladó, M., del Campo, J., Escudero, L., Rodríguez-Martínez, R., Alonso-Sáez, L., Latasa, M., Paulsen, I., Nedashkovskaya, O., Lekumberri, I., Pinhassi, J., and Pedrós-Alió, C.: Genome analysis of the proteorhodopsin-containing marine bacterium Polaribacter sp. MED152 (Flavobacteria), P. Natl. Acad. Sci. USA, 105, 87248729, 2008.

Gruber, N., Friedlingstein, P., Field, C., Valentini, R., Heimann, M., Richey, J. E., Romero-Lankao, P., Schulze, E. D., and Chen, C.-T. A.: The vulnerability of the carbon cycle in the 21 st century: an assessment of carbon-climate-human interactions, in: The global carbon cycle: integrating humans, climate, and the natural world, edited by: Field, C. B. and Raupach, M. R., 45-76, Island Press, Washington D.C., London, 2004.

Han, L., Yang, K., Kulowski, K., Wendt-Plienkowski, E., Hutchinson, C. R., and Vining, L. C.: An acyl-coenzyme A carboxylase encoding gene associated with jadomycin biosynthesis in Streptomyces venezuelae ISP5230, Microbiol. UK, 146, 903910,2000

Hartman, R. E. and Keen, N. T.: Enzymes catalysing anaplerotic carbon dioxide fixation in Verticillium albo-atrum, Phytopathol., 63, 947-953, 1973.

Hartman, R. E., Keen, N. T., and Long, M.: Carbon dioxide fixation by Verticillium albo-atrum, J. Gen. Microbiol., 73, 29-34, 1972.

Heijnen, J. J. and Roels, J. A.: A macroscopic model describing yield and maintenance relationship in aerobic fermentation processes, Biotechnol. Bioeng., 23, 739-763, 1981.

Herndl, G. J. and Reinthaler, T.: Microbial control of the dark end of the biological pump, Nat. Geosci., 6, 718-724, 2013.

Hesselsoe, M., Nielsen, J. L., Roslev, P., and Nielsen, P. H.: Isotope labeling and microautoradiography of active heterotrophic bacteria on the basis of assimilation of ${ }^{14} \mathrm{CO}_{2}$, Appl. Environ. Microb., 71, 646-655, 2005.

Hoppe, H. G., Gocke, K., Koppe, R., and Begler, C.: Bacterial growth and primary production along a north-south transect of the Atlantic Ocean, Nature, 416, 168-171, 2002.

Houghton, R. A.: Balancing the global carbon budget, Annu. Rev. Earth Planet. Sc., 35, 313-347, 2007.

Ingalls, A. E., Shah, S. R., Hansman, R. L., Aluwihare, L. I., Santos, G. M., Druffel, E. R., and Pearson, A.: Quantifying archaeal community autotrophy in the mesopelagic ocean using natural radiocarbon, P. Natl. Acad. Sci. USA, 103, 6442-6447, 2006.

Jitrapakdee, S. and Wallace, J. C.: Structure, function and regulation of pyruvate carboxylase, Biochem. J., 340, 1-16, 1999.

Jitrapakdee, S., St. Maurice, M., Rayment, I., Cleland, W. W., Wallace, J. C., and Attwood, P. V.: Structure, mechanism and regulation of pyruvate carboxylase, Biochem. J., 413, 369-387, 2008.

Kellermann, C., Selesi, D., Lee, N., Hügler, M., Esperschütz, J., Hartmann, A., and Griebler, C.: Microbial $\mathrm{CO}_{2}$ fixation potential in a tar-oil-contaminated porous aquifer, FEMS Microbiol. Ecol., 81, 172-187, 2012.

Kleiber, M., Smith, A. H., and Black, A. L.: Carbonate as precursor of milk constituents in the intact dairy cow, J. Biol. Chem., 195, 707-714, 1952.

Kornberg, H. L.: Anaplerotic sequences in microbial metabolism, Angew. Chem. Int. Edit., 4, 558-565, 1965.

Kornberg, H. L. and Krebs, E. H.: Synthesis of cell constituents from $\mathrm{C}_{2}$-units by a modified tricarboxylic acid cycle, Nature, 179, 988-991, 1957.

Kotelnikova, S. and Pedersen, K.: Distribution and activity of methanogens and homoacetogens in deep granitic aquifers at Äspö Hard Rock Laboratory, Sweden, FEMS Microbiol. Ecol., 26, 121-134, 1998.

Krebs, H. A.: Carbon dioxide assimilation in heterotrophic organisms, Nature, 147, 560-563, 1941.

Lazar, C. S., Stoll, W., Lehmann, R., Herrmann, M., Schwab, V. F., Akob, D. M., Nawaz, A., Wubet, T., Buscot, F., Totsche, K.-U., and Küsel, K.: Archaeal diversity and $\mathrm{CO}_{2}$ fixers in carbonate/siliciclastic-rock groundwater ecosystems, Archaea, 2136287, 1-13, 2017.

Le Quéré, C., Raupach, M. R., Canadell, J. G., Marland, G., Bopp, L., Ciais, P., Conway, T. J., Doney, S. C., Feely, R. A., Foster, P., Friedlingstein, P., Gurney, K., Houghton, R. A., House, J. I., Huntingford, C., Levy, P. E., Lomas, M. R., Majkut, J., Metzl, N., Ometto, J. P., Peters, G. P., Prentice, I. C., Randerson, J. T., Running, S. W., Sarmiento, J. L., Schuster, U., Sitch, S., Takahashi, T., Viovy, N., van der Werf, G. R., and Woodward, F. I.: Trends in the sources and sinks of carbon dioxide, Nat. Geosci., 2, 831-836, 2009.

Le Quéré, C., Andrew, R. M., Canadell, J. G., Sitch, S., Korsbakken, J. I., Peters, G. P., Manning, A. C., Boden, T. A., Tans, P. P., Houghton, R. A., Keeling, R. F., Alin, S., Andrews, O. D., Anthoni, P., Barbero, L., Bopp, L., Chevallier, F., Chini, L. P., Ciais, P., Currie, K., Delire, C., Doney, S. C., Friedlingstein, P., Gkritzalis, T., Harris, I., Hauck, J., Haverd, V., Hoppema, M., Klein Goldewijk, K., Jain, A. K., Kato, E., Körtzinger, A., Landschützer, P., Lefèvre, N., Lenton, A., Lienert, S., Lombardozzi, D., Melton, J. R., Metzl, N., Millero, F., Monteiro, P. M. S., Munro, D. R., Nabel, J. E. M. S., Nakaoka, S., O’Brien, K., Olsen, A., Omar, A. M., Ono, T., Pierrot, D., Poulter, B., Rödenbeck, C., Salisbury, J., Schuster, U., Schwinger, J., Séférian, R., Skjelvan, I., Stocker, B. D., Sutton, A. J., Takahashi, T., Tian, H., Tilbrook, B., van der Laan-Luijkx, I. T., van der Werf, G R., Viovy, N., Walker, A. P., Wiltshire, A. J., and Zaehle, S.: Global Carbon Budget 2016, Earth Syst. Sci. Data, 8, 605-649, https://doi.org/10.5194/essd-8-605-2016, 2016.

Lengger, S. K., Rush, D., Mayser, J. P., Blewett, J., SchwartzNarbonne, R., Talbot, H. B., Middelburg, J. J., Jetten, M. S. M., Schouten, S., Sinninghe Damsté, J. S., and Pancost, R. D.: 
Dark carbon fixation in the Arabian Sea oxygen minimum zone contributes to sedimentary organic carbon (SOM), Global Biogeochem. Cy., 33, 1715-1732, 2019.

Lliros, M., Alonso-Saéz, L., Gich, F., Plasencia, A., Auguet, O., Casamayor, E. O., and Borrego, C. M.: Active bacteria and archaea cells fixing bicarbonate in the dark along the water column of a stratified eutrophic lagoon, FEMS Microbiol. Ecol., 77, 370384, 2011

Magnabosco, C., Lin, L. H., Dong, H., Bomberg, M., Ghiorse, W., Stan-Lotter, H., Pedersen, K., Kieft, T. L., van Heerden, E., and Onstott, T. C.: The biomass and biodiversity of the continental subsurface, Nat. Geosci., 11, 707-717, 2018.

McMahon, S. and Parnell, J.: Weighing the deep continental biosphere, FEMS Microbiol. Ecol., 87, 113-120, 2014.

Melzer, E. and O'Leary M. H.: Anapleurotic $\mathrm{CO}_{2}$ fixation by phosphoenolpyruvate carboxylase in $\mathrm{C}_{3}$ plants, Plant Physiol., 84, 58-60, 1987.

Merlin, C., Masters, M., McAteer, S., and Coulson, A.: Why is carbonic anhydrase essential to Escherichia coli?, J. Bacteriol., 185, 6415-6424, 2003.

Middelburg, J. J.: Chemoautotrophy in the ocean, Geophy. Res. Lett., 38, 1-4, 2011.

Miltner, A., Richnow, H.-H., Kopinke, F.-D., and Kästner, M.: Assimilation of $\mathrm{CO}_{2}$ by soil microorganisms and transformation into soil organic matter, Org. Geochem., 35, 1015-1024, 2004.

Miltner, A., Kopinke, F.-D., Kindler, R., Selesi, D., Hartmann, A., and Kästner, M.: Non-phototrophic $\mathrm{CO}_{2}$ fixation by soil microorganisms, Plant Soil, 269, 193-203, 2005.

Molari, M., Manini, E., and Dell'Anno, A.: Dark inorganic carbon fixation sustains the functioning of benthic deep-sea ecosystems, Global Biogeochem. Cy., 27, 212-221, 2013.

Morán, X. A. G., Pérez, V., and Fernández, E.: Mismatch between community respiration and the contribution of heterotrophic bacteria in the NE Atlantic open ocean: What causes high respiration in oligotrophic waters?, J. Mar. Res., 65, 545-560, 2007.

Nel, J. A. and Cramer, M. D.: Soil microbial anaplerotic $\mathrm{CO}_{2}$ fixation in temperate soils, Geoderma, 335, 170-178, 2019.

Noguerola, I., Picazo, A., Lliros, M., Camacho, A., and Borrego, C. M.: Diversity of freshwater Epsilonproteobacteria and dark inorganic carbon fixation in the sulphidic redoxcline of a meromictic karstic lake, FEMS Microbiol. Ecol., 91, fiv086, https://doi.org/10.1093/femsec/fiv086, 2015.

Overbeck, J.: Dark $\mathrm{CO}_{2}$ uptake - biochemical background and its relevance to in situ bacterial production, Arch. Hydrobiol. Beiheft, 12, 38-47, 1979.

Palovaara, J., Akram, N., Baltar, F., Bunse, C., Forsberg, J., PedrósAlió, C., González, J. M., and Pinhassi, J.: Stimulation of growth by proteorhodopsin phototrophy involves regulation of central metabolic pathways in marine planktonic bacteria, P. Natl. Acad. Sci. USA, 111, E3650-E3658, 2014.

Parkinson, S. M., Killham, K., and Wainwright, M.: Assimilation of ${ }^{14} \mathrm{CO}_{2}$ by Fusarium oxysporum grown under oligotrophic conditions, Mycol. Res., 94, 959-964, 1990.

Parkinson, S. M., Jones, R., Meharg, A. A., Wainwright, M., and Killham, K.: The quantity and fate of carbon assimilated from ${ }^{14} \mathrm{CO}_{2}$ by Fusarium oxysporum grown under oligotrophic and near oligotrophic conditions, Mycol. Res., 95, 1345-1349, 1991.

Paulmier, A., Kriest, I., and Oschlies, A.: Stoichiometries of remineralisation and denitrification in global biogeochemical ocean models, Biogeosciences, 6, 923-935, https://doi.org/10.5194/bg6-923-2009, 2009.

Pedersen, K. and Ekendahl, S.: Assimilation of $\mathrm{CO}_{2}$ and introduced organic compounds by bacterial communities in groundwater from southeastern Sweden deep crystalline bedrock, Microb. Ecol., 23, 1-14, 1992a.

Pedersen, K. and Ekendahl, S.: Incorporation of $\mathrm{CO}_{2}$ and introduced organic compounds by bacterial populations in groundwater from deep crystalline bedrock of Stripa mine, J. Gen. Microbiol., 138, 369-376, 1992b.

Perez, R. C. and Matin, A.: Carbon dioxide assimilation by Thiobacillus novellus under nutrient-limited mixotrophic conditions, J. Bacteriol., 150, 46-51, 1982.

Reinthaler, T., Van Aken, H. M., and Herndl, G. J.: Major contribution of autotrophy to microbial carbon cycling in the deep North Atlantic, Äôs interior, Deep-Sea Res. Pt. II, 57, 15721580, 2010.

Robinson, C.: Microbial respiration, the engine of ocean deoxygenation, Front. Mar. Sci., 5, 533, https://doi.org/10.3389/fmars.2018.00533, 2019.

Robinson, C. and Williams, P. J.: Respiration and its measurement in surface marine waters, in: Respiration in aquatic ecosystems, edited by: del Giorgio, P. A. and Williams, P. J., Oxford University Press, Oxford, 2005.

Romanenko, V. I.: Heterotrophic $\mathrm{CO}_{2}$ assimilation by water bacterial flora, Mikrobiologiya, 33, 679-683, 1964.

Romanenko, V. I., Overbeck, J., and Sorokin, Y. I.: Estimation of production of heterotrophic bacteria using ${ }^{I 4} \mathrm{C}$, in: Techniques for the assessment of microbial production and decomposition in fresh waters, edited by: Sorokin, Y. I. and Kadota, H., IBP Handbook No. 23, Blackwell, Oxford, 82-85, 1972.

Roslev, P., Larsen, M. B., Jørgensen, D., and Hesselsoe, M.: Use of heterotrophic $\mathrm{CO}_{2}$ assimilation as a measure of metabolic activity in planktonic and sessile bacteria, J. Microbiol. Meth., 59, 381-393, 2004.

Santoro, A. L., Bastviken, D., Gudasz, C., Tranvik, L., and Enrich-Prast, A.: Dark carbon fixation: an important process in lake sediments, PLoS ONE, 8, e65813, https://doi.org/10.1371/journal.pone.0065813, 2013.

Šantrůčková, H., Bird, M. I., Elhottova, D., Novak, J., Picek, T., Simek, M., and Tykva, R.: Heterotrophic fixation of $\mathrm{CO}_{2}$ in soil, Microb. Ecol., 49, 218-225, 2005.

Šantrůčková, H., Kotas, P., Bárta, J., Urich, T., Čapek P., Palmtag J., Eloy Alves, R. J., Biasi, C., Diáková, K., Gentsch, N., Gittel, A., Guggenberger, G., Hugelius, G., Lashchinsky, N., Martikainen, P. J., Mikutta, R., Schleper, C., Schnecker, J., Schwab, C., Shibistova, O., Wild, B., and Richter, A.: Significance of dark $\mathrm{CO}_{2}$ fixation in arctic soils, Soil Biol. Biochem., 119, 11-21, 2018.

Sauer, U. and Eikmanns, B. J.: The PEP-pyruvate-oxaloacetate node as the switch point for carbon flux distribution in bacteria, FEMS Microbiol. Rev., 29, 765-794, 2005.

Schink, B.: An alternative to the glyoxylate shunt, Mol. Microbiol., 73, 975-977, 2009.

Schinner, F., Concin, R., and Binder, H.: Heterotrophic $\mathrm{CO}_{2-}$ fixation by fungi in dependence on the concentration of the carbon source, Phyton, 22, 81-85, 1982.

Scrutton, M. C.: Assay of enzymes of $\mathrm{CO}_{2}$ metabolism, Method. Microbiol., 6, Part A, 479-541, 1971. 
Signori, C. N., Valentin, J. L., Pollery, R. C. G., and Enrich-Prast, A.: Temporal variability of dark carbon fixation and bacterial production and their relation with environmental factors in a tropical estuarine system, Estuar. Coast., 41, 1089-1101, 2017.

Smith, A. R., Kieft, B., Mueller, R., Fisk, M. R., Mason, O. U., Popa, R., and Colwell, F. S.: Carbon fixation and energy metabolisms of a subseafloor olivine biofilm, ISME J., 13, 17371749, 2019.

Spohn, M., Müller, K., Höschen, C., Mueller, C. W., and Marhan, S.: Dark microbial $\mathrm{CO}_{2}$ fixation in temperate forest soils increases with $\mathrm{CO}_{2}$ concentrations, Glob. Change Biol., 26, 19261935, 2019.

Spona-Friedl, M., Braun, A., Huber, C., Eisenreich, W., Griebler, C., Kappler, A., and Elsner, M.: Substrate-dependent $\mathrm{CO}_{2}$-fixation in heterotrophic bacteria revealed by stable isotope labelling, FEMS Microbiol. Ecol., 96, fiaa080, https://doi.org/10.1093/femsec/fiaa080, 2020.

Strong, P. J., Xie, S., and Clarke, W. P. Methane as a resource: can the methanotrophs add value?, Environ. Sci. Technol., 49, 40014018, 2015.

Swan, B. K., Martinez-Garcia, M., Preston, C. M., Sczyrba, A., Woyke, T., Lamy, D., Reinthaler, T., Poulton, N. J., Masland, E. D. P., Lluesma Gomez, M., Sieracki, M. E., DeLong, E. F., Herndl, G. J., and Stepanauskas, R.: Potential for chemolithoautotrophy among ubiquitous bacteria lineages in the dark ocean, Science, 333, 1296-1300, 2011.

Tait, L. W. and Schiel, D. R.: Impacts of temperature on primary productivity and respiration in naturally structured macroalgal assemblages, PLoS ONE, 8, e74413, https://doi.org/10.1371/journal.pone.0074413, 2013.

Teiro, E., Fernández, A., Álvarez-Salgado, X. A., García-Martín, E. E., Serret, P., and Sobrino, C.: Response of two marine bacterial isolates to high $\mathrm{CO}_{2}$ concentration, Mar. Ecol.-Prog. Ser., 453, 27-36, 2012.

Tempest, D. W. and Neijssel, O. M.: Physiological and energetic aspects of bacterial metabolite overproduction, FEMS Microbiol. Lett., 100, 169-176, 1992.

Tuttle, J. H. and Jannasch, H. W.: Microbial dark assimilation of $\mathrm{CO}_{2}$ in the Cariaco Trench, Limnol. Oceanogr., 24, 746-753, 1979.

Vasquez-Cardenas, D., Meysman, F. J. R., and Boschker, H. T. S.: A cross-system comparison of dark carbon fixation in coastal sediments, Global Biogeochem. Cy., 34, 1-14, 2020.

Vick-Majors, T. J. and Priscu, J. C.: Inorganic carbon fixation in icecovered lakes of the McMurdo Dry Valleys, Antarctic Sci., 1-10, https://doi.org/10.1017/S0954102019000075, 2019.

von Stockar, U., Maskow, T., Liu, J., Marison, I. W., and Patiño, R.: Thermodynamics of microbial growth and metabolism: An analysis of the current situation, J. Biotechnol., 121, 517-533, 2006.

Wegener, G., Bausch, M., Holler, T., Thang, N. M., Mollar, X. P., Kellermann, M. Y., Hinrichs, K. U., and Boetius, A.: Assessing sub-seafloor microbial activity by combined stable isotope probing with deuterated water and ${ }^{13} \mathrm{C}$-bicarbonate, Environ. Microbiol., 14, 1517-1527, 2012.
Werkman, C. H. and Wood, H. G.: Heterotrophic assimilation of carbon dioxide, in: Advances in Enzymology and Related Areas of Molecular Biology, edited by: Nord, F. F., 2, 135-182, Interscience Publishers, Inc., 1942.

Whitman, W. B., Coleman, D. C., and Wiebe, W. J.: Prokaryotes: The unseen majority, P. Natl. Acad. Sci., 95, 6578-6583, 1998.

Wood, H. G. and Stjernholm, R. L.: Assimilation of carbon dioxid by heterotrophic organisms, in: The Bacteria: A Treatise on Structure and Function, Vol. 3, edited by: Gunsalus, I. C. and Stanier, R. Y., Biosynthesis Academic Press, New York, 41-117, 1962.

Wood, H. G. and Werkman, C. H.: The utilisation of $\mathrm{CO}_{2}$ in the dissimilation of glycerol by the propionic acid bacteria, Biochem. J., 30, 48-53, 1936.

Wood, H. G. and Werkman, C. H.: The utilization of $\mathrm{CO}_{2}$ by the propionic acid bacteria, Biochem. J., 32, 1262-1271, 1938.

Wood, H. G. and Werkman, C. H.: The position of carbon dioxidecarbon in succinic acid synthesized by heterotrophic bacteria, J. Biol. Chem., 139, 377-381, 1941.

Wuchter, C., Schouten, S., Boschker, H. T. S., and Sinninghe Damsté, J. S.: Bicarbonate uptake by marine Crenarchaeota, FEMS Microbiol. Lett., 219, 203-207, 2003.

Yakimov, M. M., La Cono, V., Smedile, F., Crisafi, F., Arcadi, E., Leonardi, M., Decembrini, F., Catalfamo, M., Bargiela, R., Ferrer, M., Golyshin, P. N., and Giuliano, L.: Heterotrophic bicarbonate assimilation is the main process of de novoorganic carbon synthesis in hadal zone of the Hellenic Trench, the deepest part of Mediterranean Sea, Environ. Microbiol. Rep., 6, 709-722, 2014.

Zhang, Y., Qin, W., Hou, L., Zakem, E. J., Wan, X., Zhao, Z., Liu, L., Hunt, K. A., Jiao, N., Kao, S.-J., Tang, K., Xie, X., Shen, J., Li, Y., Chen, M., Dai, X., Liu, C., Deng, W., Dai, M., Ingalls, A. E., Stahl, D. A., and Herndl, G. J.: Nitrifier adaptation to low energy flux controls inventory of reduced nitrogen in the dark ocean, P. Natl. Acad. Sci. USA, 117, 4823-4830, 2020.

Zhao, Y., Liu, P., Rui, J., Cheng, L., Wang, Q., Liu, X., and Yuan, Q.: Dark carbon fixation and chemolithotrophic microbial community in surface sediments of the cascade reservoirs, Southwest China, Sci. Total Environ., 698, 134316, https://doi.org/10.1016/j.scitotenv.2019.134316, 2020.

Zhou, W., Liao, J., Guo, Y., Yuan, X., Huang, H., Yuan, T., and Liu, S.: High dark carbon fixation in the tropical South China Sea, Cont. Shelf Res., 146, 82-88, 2017.

Zopfi, J., Ferdelman, T. G., Jørgensen, B. B., Teske, A., and Thamdrup, B.: Influence of water column dynamics on sulfide oxidation and other major biogeochemical process in the chemocline of Mariager Fjord (Denmark), Mar. Chem., 74, 29-51, 2001. 